\title{
What impact does teaching music informally in the classroom have on teachers, and their pedagogy?
}

Prof. Susan Hallam, Dr Andrea Creech, Dr Hilary McQueen, UCL Institute of Education

\section{Introduction}

Informal learning in music is well-established in the Nordic countries, in particular in Sweden.

Since the 1960s educational policy in Sweden has focused on the entitlement of each student to have his or her individual needs and interests to be recognised in school. In music this has meant an emphasis on building on the students' extra-curricular music activities in the classroom. As a result popular music has been part of the compulsory school music curricula since the 1970s usually taught informally through a process based on the way that popular musicians learn (Karlsen \& Vakeva, 2012). The content of music lessons is developed by each teacher jointly with his or her students, with the emphasis being on practical music making based on either large group singing or small group pop and rock groups copying, by ear, predominantly easy pop and rock songs from the 1950s and onwards. The idea is that through informal pedagogy students will influence and control the content and the pace of their own learning and that this will meet their needs and increase motivation. Despite this students have indicated that while they enjoy school music they find it old fashioned and excluding many genres (Skolverket, 2004). The use of computers or DJ equipment is exceptional and few students engage in composition as creating is not a central goal (GeorgiiHemming, 2006). There is large variability between schools as teachers design their own curriculum based their own musical competencies and the students' leisure music (GeorgiiHemming and Westvall, 2010). The approach has also been criticised because of a lack of progression with teaching being short-term, unplanned and populist with many one-off activities which contribute to a lack of continuity (Georgii-Hemming and Westvall, 2010; Skolverket, 2004). While teachers are better connected with students' musical preferences and leisure activities, this seems to mainly benefit those who play instruments as a leisure activity (Skolverket, 2004). Some 
groups of students become disengaged when what is offered does not meet their needs (Bergman, 2009). These limitations have led to considerable debate as to whether music education has become too individualised and informal and whether there should there be a better balance between formal and informal learning (Georgii-Hemming and Westvall, 2012).

In the UK, the adoption of informal learning practices in music is more recent than that in the Nordic countries and developed in response to concerns about the place of music in the secondary school curriculum. In England there were and continue to be low levels of take-up of music at Key Stage 4 (aged 14 to 16) and at Key Stage 5 (aged 16 to 18) when music is optional (McQueen \& Hallam, 2010), this despite the fact that students enjoy music (Lamont et al., 2003), value the opportunities to work practically and indicate that music increases their self-esteem, particularly when they can perform to others (Ofsted, 2009; Hallam et al., 2009). Some have suggested that the lack of take up is because of the poor quality of the teaching. National inspection reports support this revealing wide differences in the quality of teaching at secondary level (Ofsted, 2003, 2009, 2011) further supported by differences in the take up of music at KS4 and KS5 (Little, 2009). In addition, there is evidence of a widely held perception that it is necessary to have high level instrumental skills in order to continue with music and take national examinations at age 16 and 18 (Lamont et al., 2003; Wright, 2002). Indeed, some music teachers have been found to discourage pupils with no instrumental skills from continuing with music as an option (Ofsted, 2009). Young people with high level instrumental or vocal skills may see no need to continue with music at KS4 unless they wish to pursue a career in music (Little, 2009) particularly as music is perceived to have little value in career terms in the wider community (Lamont et al., 2003; Hallam et al., 2009). Parents also sometimes persuade their children from taking music (Button, 2006; Hallam et al., 2009). 
In response to these concerns, the Musical Futures (MF) approach was developed to devise new and imaginative ways of engaging young people, aged 11-19, in musical activities providing all children with opportunities to engage with music that interests them and be empowered to take control of their musical learning (Finney \& Philpott, 2010). Student centred pedagogies were developed characterised by the teacher facilitating learning rather than directing it and pupils being involved in determining the nature of the curriculum. The Musical Futures approach was launched in 2003 and emerged from research which focused on how musicians working in popular genres learned through listening and playing by ear (Green, 2002; 2008). It was developed between 2004 and 2006 in three Local Authority Music Services, in Leeds, Nottingham and Hertfordshire. From the pilot work four key strands of the Musical Futures programme were developed. Informal Music Learning at Key Stage 3 was based on the real-life learning practices and processes of popular musicians, enabling students to learn alongside friends, through independent, self-directed learning with teachers acting as facilitators and musical models. The Whole Curriculum Approach was a scheme of work for Year 8 students who had not previously experienced sustained musical engagement, which included providing extra support for the teacher, bringing informal learning processes into schools, making tangible connections with students' musical lives outside school, and involving students in real musical activity, in genuine musical situations and environments. Personalising Extra-Curricular Music constituted a guide for personalising extra-curricular music projects so that they complemented the curricular work in schools and enhanced students' musical progression, while NUMU (www.numu.org.uk) was an interactive web space for creating music, publishing, marketing and promoting, allowing students to develop skills and apply them to a real life situation with a global audience. Following the pilot work a toolkit of teacher resources was published which included written materials, such as lesson plans and National Curriculum mapping, video and audio material, as well as case studies and quotes from participating teachers and students (www.musicalfutures.org). Between 2006 and 2008, a two-year CPD programme was offered followed, in 2008, by the establishment of a national network of 'Champion Schools' that adapted and adopted Musical Futures independently (d'Amore, 2014). 
While, the overall pedagogical approach of Musical Futures has not changed since its inception, based on increasing knowledge of how teachers adapt and apply the pedagogy in a range of classroom situations two main approaches have been identified: Informal learning, where students set their objectives and learn in a self-directed manner starting with familiar music, moving on to other genres and ultimately composition with the teacher modelling, supporting, advising and guiding; and non-formal teaching which involves techniques based on community music practice where fully inclusive group-based activities in performing, listening, composing and improvising are undertaken with teachers and students co-constructing content. This has led to a new definition of Musical Futures as 'an approach to teaching and learning.... a new way of thinking about musicmaking in schools that brings non-formal teaching and informal learning approaches into the more formal context of schools (Musical Futures, 2014, p 9).

In 2008, a survey of Musical Futures revealed that about 700 teachers were either using or planning to use the Musical Futures materials. The majority of survey respondents reported that they made use of the informal music learning model, although about a quarter either used or planned to use the Whole Curriculum Approach or NUMU with a smaller number using or planning to use the model for Personalising Extra-Curricular Music. The approaches were most often used with Year 9 groups (aged 13-14 years) least frequently with Year 7 (aged 11-12 years) and typically over the course of an entire academic year. The key expectations of those planning to implement Musical Futures were that it would increase motivation, provide a more stimulating curriculum, raise standards, enhance musical skills, provide professional development, and increase the numbers of students taking the General Certificate of School Education (GCSE) in music (Hallam et al., 2008).

There has been considerable interest in the impact of the Musical Futures approach and several evaluations have been undertaken. These have tended to focus on the outcomes for students (see Benson, 2012; Evans, Beauchamp \& John, 2015; Hallam et al., in revision; Jeanneret, 2010; 
Jeanneret et al., 2012; John \& Evans, 2013; O’Neill \& Bespflug, 2011; Younker et al., 2012).

Little research has focused on the impact on the teachers who are ultimately key to its

implementation. A national inspection report, on the pilot work in the UK indicated that teachers were enthused by the opportunity to rethink their approach to teaching music and concluded that the project challenged many assumptions about musical learning and offered effective alternatives to established teaching approaches. Jeannerett and colleagues (2012) studied the implementation of the Musical Futures approach after two or three terms in ten Victorian government schools in Australia. Eleven music teachers participated completing questionnaires about the approach. They were largely well qualified in education with many having formal qualifications in contemporary popular music and jazz as well as professional performing experience. The research also included two case study schools, one primary and one secondary. The teachers in these schools were interviewed. The findings indicated that the implementation of Musical Futures had a powerful impact on teachers' confidence, pedagogy and professional satisfaction. Teachers indicated that they had changed their approach to teaching music and that they had encountered few difficulties in implementing the programme. Those reported included lack of support from instrumental teachers and the cost of implementation.

Gower (2012), a secondary school music teacher, drawing on her own experiences and those of colleagues set out the issues for the implementation of the Musical Futures approach in the current educational environment in England outlining the challenges that music teachers face. She argued that many of what are perceived as non-negotiable practices in schools including planned seating, homework set in every lesson, literacy addressed in the lesson as well as in marking and students knowing the National Curriculum level at which they are working do not sit easily with the Musical Futures approach. Lessons where clear structures are expected are not feasible where the learning is student led. She also described how teachers are under increasing pressure to meet rigid targets as a means to measure school effectiveness in a climate of league tables and the aim to 'add value' throughout the secondary school experience. These factors act as barriers to the implementation of 
the workshopping approach which is needed to facilitate student learning informally. She also suggested that other school staff viewed the informal approach of Musical Futures as too innovative and reported that there were frequently complaints about noise levels.

Given the relative paucity of research on the impact of the implementation of the Musical Futures approach on teachers and their pedagogy, the aim of the research reported here was to explore the impact of the adoption of the Musical Futures approach on the skills and pedagogy of teachers working in eight Musical Futures Champion Schools. The specific research questions were:

- To what extent has the adoption of Musical Futures impacted on participating teachers' professional development (including their confidence, enjoyment, acquisition of new skills, relaxation and stress)?

- To what extent has Musical Futures impacted on teachers' pedagogy (including their knowledge of students musical preferences outside school, changes made to the Musical Futures approach to meet their own needs and those of their students, their classroom practices including group work, personalised learning, inclusion of classical and popular music and the inclusion of all students and classes)?

- To what extent has musical futures impacted on assessment in the classroom and in relation to national examinations?

- To what extent are there issues relating to resources in relation to adopting the Musical Futures approach?

- What are the perceived challenges associated with adopting the Musical Futures approach?

\section{Methods}

The research was carried out over a three year period in three phases in six case study Champion schools. Two additional schools were recruited for the completion of questionnaires to increase the sample size and also to ensure that should one of the case study schools drop out of the study 
replacements would be available. During Phase 1, staff from eight schools completed the questionnaire. One school dropped out after Phase 1. Phases 2 and 3 included the remaining seven schools.

\section{The questionnaire}

The questionnaires requested information about the teachers' qualifications, their teaching experience and the instruments that they played. They were also asked about the elements of the Musical Futures approach which had been adopted in their school, the year groups where it was adopted, and the length of time of the adoption. They were also asked to strongly agree, agree, disagree or strongly disagree with a range of statements. These focused on three main themes, the impact of adopting the Musical Futures approach on them, their teaching, and resources. The impact of adopting Musical Futures on them as teachers included statements relating to the impact on their perceived effectiveness, their confidence in relation to teaching different musical skills, their enjoyment of teaching, the development of new skills, and whether they were relaxed or stressed when teaching. In relation to pedagogy the statements focused on their knowledge of the music that the students engaged with outside of school, the extent they adapted Musical Futures to their approach to pedagogy and to meet the needs of their students, the extent to which the Musical Futures approach impacted on their teaching being student led, practical, personalised, included popular and classical music, was based on new ideas and was appropriate for classes of all sizes and all students. The final group of statements focused on resources including the number of practice rooms, musical instrument and equipment resources and time, The full statements are set out in the findings Tables. Teachers were also given the opportunity to add any additional information that they felt was relevant. The questionnaire was piloted with a group of teachers adopting the Musical Futures approach who were not involved in the main research project.

\section{The interviews}


The interviews were semi-structured allowing flexibility and the opportunity for interviewees to raise issues of importance to them (Cohen et al. 2003). Individual interviews were carried out with music staff during Phases 1, 2 and 3. The interviews followed up responses from the questionnaires in more depth and also included questions about assessment (in class and in relation to national examinations) and the challenges of adopting the Musical Futures approach. The questions related to their perceptions of the impact on them and their teaching were:

What has been the impact of Musical Futures on your confidence and professional satisfaction?

How has implementing the Musical Futures approach impacted on your pedagogy?

What has been the impact of the Musical Futures approach on assessment?

Have there been any implications for resources on adopting the Musical Futures approach?

Has the adoption of the Musical Futures created any particular challenges?

\section{Data analysis}

The questionnaire data were analysed using SPSS. The interviews were transcribed in full.

Interview data were themed following the guidelines set out by Braun and Clarke (2006), familiarising oneself with the data through reading transcripts a number of times, generating initial codes, searching for themes and reviewing, defining and naming themes.

\section{The case study schools}

The case study schools were selected to represent different types of school and differences in experience with Musical Futures. The characteristics of the schools are set out in Table 1. 
Table 1: Case study schools

\begin{tabular}{|c|c|c|c|c|c|c|c|}
\hline School & $\begin{array}{l}\text { Specialist } \\
\text { status }\end{array}$ & $\begin{array}{l}\text { Number } \\
\text { on roll }\end{array}$ & Ethnic make up & FSM & EAL & $\begin{array}{l}\text { OFSTED } \\
\text { grade }\end{array}$ & $\begin{array}{l}\text { Music exams } \\
\text { taken in KS4 }\end{array}$ \\
\hline School A & Technology & 1416 & $\begin{array}{l}\text { Mainly White } \\
\text { British }\end{array}$ & Low & Low & Satisfactory & BTEC \\
\hline $\begin{array}{l}\text { School B } \\
\text { Boys school }\end{array}$ & Arts & 1447 & $\begin{array}{l}\text { Over } 50 \% \text { black } \\
\text { and minority } \\
\text { ethnic } \\
\text { backgrounds }\end{array}$ & High & High & Good & BTEC \\
\hline School C & $\begin{array}{l}\text { Language } \\
\text { and } \\
\text { technology }\end{array}$ & 1790 & $\begin{array}{l}\text { Mainly White } \\
\text { British }\end{array}$ & Low & Low & Outstanding & GCSE \\
\hline School D & Science & 1286 & $\begin{array}{l}\text { Mainly minority } \\
\text { ethnic } \\
\text { backgrounds }\end{array}$ & High & High & Satisfactory & BTEC \\
\hline School E & Science & 1223 & $\begin{array}{l}\text { Mainly White } \\
\text { British }\end{array}$ & Low & Low & Satisfactory & $\begin{array}{l}\text { GCSE } \\
\text { Rockschool }\end{array}$ \\
\hline School F & Visual arts & 956 & $\begin{array}{l}\text { Mainly White } \\
\text { British }\end{array}$ & Low & Low & Outstanding & GCSE \\
\hline School G & Visual arts & 806 & $\begin{array}{l}\text { Mainly White } \\
\text { British }\end{array}$ & Low & Low & Outstanding & GCSE \\
\hline
\end{tabular}

$* \mathrm{FSM}=$ free school meals; $\mathrm{EAL}=$ English as an additional language

\section{Music staff}

During Phase 1, 28 music teachers, representing a range of experience of Musical Futures,

completed the questionnaire. Six responses were from Heads of Music, eight from full-time music teachers, four from part-time teachers, two from trainee teachers on Post Graduate Certificate in Education placements, four from technicians and three from those describing their positions in other ways. Table 2 sets out the instruments played by the music teachers.

Table 2: Instruments played by music staff

\begin{tabular}{|l|c|c|c|c|c|c|c|c|}
\hline & $\begin{array}{l}\text { First } \\
\text { instrument }\end{array}$ & & $\begin{array}{l}\text { Second } \\
\text { instrument }\end{array}$ & $\begin{array}{l}\text { Third } \\
\text { instrument }\end{array}$ & $\begin{array}{l}\text { Fourth } \\
\text { instrument }\end{array}$ & \\
\hline Voice & 3 & $11 \%$ & 2 & $8 \%$ & 1 & $5 \%$ & 2 & $20 \%$ \\
\hline Piano/Keyboard & 7 & $26 \%$ & 8 & $32 \%$ & 5 & $26 \%$ & 1 & $10 \%$ \\
\hline Brass instrument & 3 & $11 \%$ & & & 1 & $5 \%$ & 1 & $10 \%$ \\
\hline String instrument & 3 & $11 \%$ & 3 & $12 \%$ & 1 & $5 \%$ & & \\
\hline Woodwind & 5 & $18 \%$ & 3 & $12 \%$ & 4 & $21 \%$ & 3 & $30 \%$ \\
\hline Percussion & 3 & $11 \%$ & 1 & $4 \%$ & 5 & $26 \%$ & 1 & $10 \%$ \\
\hline Guitar & 3 & $11 \%$ & 7 & $28 \%$ & 2 & $10 \%$ & 2 & $20 \%$ \\
\hline Organ & & & 1 & $4 \%$ & & & & \\
\hline
\end{tabular}


The grades attained in Associated Board of the Royal Schools of Music examinations on first and second instruments varied between grade 5 and 8 . Twenty- four had attained grade 8 on their first instrument and twenty-five on their second instrument. Fourteen had attained grade 8 on their third instrument. Fewer teachers played a fourth instrument and the standard here was lower at grade 4 or 5.

Twenty of the teachers participated in some kind of musical group, 13 in two groups and six in three groups. Eight played in an orchestra, six sang in a choir, six played in a rock/pop band, five in a funk/jazz/disco band, three in a brass band, three in a chamber music group and individuals in unspecified ensembles, wind band, show band, steel band or Taiko drumming. Two were conductors and one an accompanist.

Twenty seven indicated that they had an A level music qualification, nine had a music diploma, and 27 had a music degree. Other qualifications held included a masters degree, a Postgraduate Certificate in Education or a Certificate in Education.

\section{Implementation of the Musical Futures approach}

Five of the music teachers indicated that they used Musical Futures with Year 7, 22 with Year 8, 22 with Year 9, one with Year10 and four with Year11. Eleven used the Whole Curriculum Approach, 21 informal music learning at Key Stage 3, 16 NUMU, and two Personalising the curriculum. Twelve used Musical Futures for the whole academic year, eight for one term, three for one or more units of work and one for an occasional lesson.

The number of years of teaching experience varied from 0 to 28. The most experience of working with Musical Futures was five years (2 teachers). Some teachers had been involved in the pilot 
work. Table 3 sets out the length of time that the music teachers had been engaged with Musical

Futures work.

Table 3: Music Teachers' experience of working with Musical Futures

\begin{tabular}{|l|c|c|}
\hline Length of time & Number & Percentage \\
\hline Involved in pilot & 1 & 4 \\
\hline 5 years & 2 & 9 \\
\hline 3 years & 2 & 9 \\
\hline 2 years & 2 & 17 \\
\hline 1 year & 4 & 17 \\
\hline 2 terms & 4 & 13 \\
\hline 1 term & 3 & 4 \\
\hline While on teaching practice & 1 & 9 \\
\hline Some/a little & 2 & 9 \\
\hline None & 2 & \\
\hline
\end{tabular}

\section{Findings}

\section{The impact on teachers' perceived effectiveness, confidence and enjoyment}

Most teachers (76\%) indicated that Musical Futures had helped them to become a more effective teacher. $61 \%$ indicated that Musical Futures had helped them become more confident about teaching music and $81 \%$ that Musical Futures had increased their enjoyment in teaching music.

There was less agreement that Musical Futures had increased confidence in facilitating learning in a range of musical genres (62\%) and in singing (44\%). In contrast $77 \%$ indicated increased confidence in teaching instrumental skills and $65 \%$ that they had developed new instrumental skills. There was less agreement (54\%) that Musical Futures had helped them to feel more relaxed in the classroom, while 52\% indicated that they found Musical Futures teaching stressful (see Table 4). The data from the interviews provided deeper insights into these responses. 
Table 4: Impact on teachers' perceived effectiveness, confidence, enjoyment and stress

\begin{tabular}{|l|l|l|l|l|l|l|}
\hline & $\begin{array}{l}\text { Strongly } \\
\text { agree }\end{array}$ & Agree & Disagree & $\begin{array}{l}\text { Strongly } \\
\text { disagree }\end{array}$ & Mean & SD \\
\hline $\begin{array}{l}\text { Musical Futures has helped me to } \\
\text { become a more effective teacher }\end{array}$ & $28 \%(7)$ & $48 \%(12)$ & $24 \%(6)$ & & 3.0 & .7 \\
\hline $\begin{array}{l}\text { Musical Futures has helped me to be } \\
\text { more confident about teaching music }\end{array}$ & $23 \%(6)$ & $39 \%(10)$ & $39 \%(10)$ & & 2.8 & .8 \\
\hline $\begin{array}{l}\text { Musical Futures has increased my } \\
\text { enjoyment of teaching music }\end{array}$ & $23 \%(6)$ & $58 \%(15)$ & $19 \%(5)$ & & 3.0 & .7 \\
\hline $\begin{array}{l}\text { Musical Futures has increased my } \\
\text { confidence in facilitating singing }\end{array}$ & $4 \%(1)$ & $40 \%(10)$ & $48 \%(12)$ & $8 \%(2)$ & 2.4 & .7 \\
\hline $\begin{array}{l}\text { Musical Futures has increased my } \\
\text { confidence in teaching instrumental } \\
\text { skills }\end{array}$ & $23 \%(6)$ & $54 \%(14)$ & $23 \%(6)$ & & 3.0 & .7 \\
\hline $\begin{array}{l}\text { Musical Futures has increased my } \\
\text { confidence in facilitating student } \\
\text { learning in a range of musical genres }\end{array}$ & $4 \%(1)$ & $58 \%(15)$ & $38 \%(10)$ & & 2.7 & .6 \\
\hline $\begin{array}{l}\text { Musical Futures has helped me to } \\
\text { develop new instrumental skills }\end{array}$ & $27 \%(7)$ & $38 \%(10)$ & $35 \%(9)$ & & 2.9 & .8 \\
\hline $\begin{array}{l}\text { Musical Futures has helped me to feel } \\
\text { more relaxed in the classroom }\end{array}$ & $19 \%(5)$ & $35 \%(9)$ & $46 \%(12)$ & & 2.7 & .8 \\
\hline $\begin{array}{l}\text { I do not find Musical Futures teaching } \\
\text { stressful }\end{array}$ & $16 \%(4)$ & $32 \%(8)$ & $40 \%(10)$ & $12 \%(3)$ & 2.5 & .9 \\
\hline
\end{tabular}

Figures in brackets indicate the number of respondents

Teacher confidence: Some teachers reported that Musical Futures had given them opportunities to develop experience in areas where they previously had few skills and as a result their confidence had increased:

'Well I always thought I was a confident teacher but I think definitely through the Musical Futures work I've become more confident, especially in group work and band work.' (Music Teacher)

'My confidence has improved and it's developed me, like delivering training to the whole staff which I never would have done before and that's a direct result of Musical Futures. I was on Radio 1 because of Musical Futures.' (Head of Music)

Some teachers were very apprehensive initially about adopting Musical Futures but gained in confidence: 
'I know S [teacher] was actually very scared of Musical Futures at first but she's come through it and enjoyed doing it. It's given me confidence really because normally you're a teacher in charge of a classroom. In this sort of aspect you're not as in charge but when you get the results when they do the performances it gives you confidence because students have actually done this, they've taken on board what you've said. So my confidence certainly has increased through it.' (Head of Music)

Apprehension was expressed by one teacher:

'I think the first few years you can have problems with it because you're not used to needing the skills you need in Musical Futures, and being able to send groups off and just trust they're on task. You're going to find behaviour problems in Year 9. It's such a difficult thing to do but then once you've got it you can go into any class to teach because you've already given them so much freedom you can bring them back much easier.' (Head of Music)

The key issue for teachers to address in learning how to facilitate group work was the reduction of control:

'The first time I did Musical Futures it was a little bit more stressful because you get less control, it's the whole control freak thing... handing it over to the students is quite frightening at first. When you get used to it, you still set the boundaries, the students get used to it, they know what they're doing a bit more.' (Music Teacher)

Newly qualified teachers (NQTs) involved with Musical Futures gained confidence as they engaged with it:

'The NQT this year started off very formal, very controlling over what was happening, very teacher-led. But one class that she teaches are incredible and have produced amazing results and 
she buzzes about that. So then she wants to share it with other teachers, so it opens up channels of communication that way.' (Head of Music)

There were some reported benefits to the department as a whole:

'I think we've really enjoyed it as team. I think it's brought us together as a department. I've recently done the Salsa project as a pilot and we learnt all the parts together and kind of worked them out, and tried different instruments and roles.' (Head of Music)

Teacher enjoyment and satisfaction: In the interviews teachers reported that teaching Musical Futures was professionally very satisfying. The nature of the process meant that they had to hand over control to the students. While this could be anxiety provoking it also contributed to the satisfaction felt when the students succeeded. The feedback that teachers received indirectly through students' enthusiasm and motivation was also rewarding:

'I get a lot of professional satisfaction from it. You go through this sort of, you know, week three or four, where you wonder what are they doing and then there are suddenly moments, amazing moments, those special moments in music education certainly where suddenly you hear someone sing for the first time and you think "wow isn't that amazing”. ' (Music Teacher)

'Professional satisfaction is great because there's loads of kids wanting to do music. Not just in lessons but kids coming lunchtimes, after school. It was their idea to have a concert so the buzz around it is great.' (Head of Music)

Satisfaction was also derived from the high quality of work although there were moments when things did not work well: 
'It's satisfying because you do get really good results. Not always, but I think it's raised the standard from what Year 9s produced before. It can be more difficult because you've got to be really organised, otherwise you're running all over the place.' (Music Teacher)

'When it's going really well it's really good. On the other hand it can make you feel shockingly bad - someone's hit a kid over the head with a guitar, various things, so in that way it can be very, very de-motivating. It's got its ups and downs definitely.' (Music Teacher)

Overall, the teachers reported enjoying teaching using Musical Futures.

Teacher stress: Teachers were divided as to whether they believed that implementing Musical Futures was stressful (see Table 4). Any stress experienced was because of the nature of the work:

'It's hard. It's hard to teach because you've got be 100\% committed to every lesson that you do. If you do it half-heartedly you lose them. It's not something you can opt in and opt out of. It's exhausting for a teacher. You've got to be continually on the go. You're challenged from what you're asked to do, pick out a bass line, play some chords, help you do this, print something off the internet.' (Head of Music)

Some teachers liked the stimulation but others found it difficult to cope with. Stress was also related to the perceived lack of control and the way other people might view the situation:

'It can be really stressful for the teacher. I think you have to go into it with this sort of positive attitude. You have to say, well, actually this is going to be chaotic. This is going to be up in the air. This is going to be loose... I think as a teacher you're very conscious of what your colleagues perceive is going on in your lessons. You've got this situation where they're looking for drum sticks and leads and mics and they're all in a room and they're shouting and arguing with each other 
because they've decided who's going to play what but he's not in today and da, da, da, and he's forgotten his CD. It can be utterly chaotic.' (Music Teacher)

Some teachers may experience 'burn-out' because of the demanding nature of the work:

'Energy. I die at the end of the day. I think that's not acknowledged enough by the powers that be. If you are workshopping lesson after lesson after lesson in a six period day, it is exhausting so I think optimal conditions are having a lot of energy, and having time off between to recharge because you are giving out a lot.' (Head of Music)

\section{Impact on pedagogy}

Almost all of the teachers (92\%) agreed that they had adapted Musical Futures to fit with their personal approach to teaching and learning, that they had adapted Musical Futures to meet the individual needs of their students (92\%), that their lessons were more student led (92\%) and that Musical Futures had encouraged more group music making. The majority agreed that lessons were more practical $(81 \%)$, that teaching was more personalised (88\%) and that Musical Futures had increased their awareness of the music that their students engage in outside of school. Table 5 provides a breakdown of responses. All of teachers agreed that Musical Futures allowed for more emphasis on popular music and had introduced new ideas into the classroom but only $30 \%$ agreed that it allowed for the exploration of classical music. $48 \%$ agreed that it worked with classes of all sizes, and $54 \%$ that it worked equally well with all students. 
Table 5: Impact on pedagogy

\begin{tabular}{|c|c|c|c|c|c|c|}
\hline & $\begin{array}{l}\text { Strongly } \\
\text { agree }\end{array}$ & Agree & Disagree & $\begin{array}{l}\text { Strongly } \\
\text { disagree }\end{array}$ & Mean & SD \\
\hline $\begin{array}{l}\text { Musical Futures has increased my } \\
\text { awareness of the music that students } \\
\text { engage in outside of school }\end{array}$ & $27 \%(7)$ & $54 \%(14)$ & $19 \%(5)$ & & 3.1 & .7 \\
\hline $\begin{array}{l}\text { I have adapted Musical Futures to fit } \\
\text { with my personal approach to teaching } \\
\text { and learning }\end{array}$ & $31 \%(8)$ & $61 \%(16)$ & $8 \%(2)$ & & 3.2 & .6 \\
\hline $\begin{array}{l}\text { I have adapted Musical Futures to meet } \\
\text { the individual needs of my students }\end{array}$ & $24 \%(6)$ & $68 \%(17)$ & $8 \%(2)$ & & 3.2 & .6 \\
\hline $\begin{array}{l}\text { Musical Futures has made my lessons } \\
\text { more student-led }\end{array}$ & $44 \%(11)$ & $48 \%(12)$ & $8 \%(2)$ & & 3.4 & .6 \\
\hline $\begin{array}{l}\text { Musical Futures has made my lessons } \\
\text { more practical }\end{array}$ & $54 \%(14)$ & $27 \%(7)$ & $19 \%(5)$ & & 3.3 & .8 \\
\hline $\begin{array}{l}\text { Musical Futures has made my teaching } \\
\text { more personalised }\end{array}$ & $36 \%(9)$ & $52 \%(13)$ & $12 \%(3)$ & & 3.2 & .7 \\
\hline $\begin{array}{l}\text { Musical Futures has encouraged more } \\
\text { group music making }\end{array}$ & $38 \%(10)$ & $54 \%(14)$ & $8 \%(2)$ & & 3.3 & .6 \\
\hline $\begin{array}{l}\text { Musical Futures allows for more } \\
\text { emphasis on popular music }\end{array}$ & $19 \%(5)$ & $81 \%(21)$ & & & 3.8 & .4 \\
\hline $\begin{array}{l}\text { Musical Futures encourages exploration } \\
\text { of classical music }\end{array}$ & & $20 \%(5)$ & $64 \%(16)$ & $16 \%(4)$ & 2.0 & .6 \\
\hline $\begin{array}{l}\text { Musical Futures has introduced new } \\
\text { ideas into the classroom }\end{array}$ & $46 \%$ (12) & $54 \%$ (14) & & & 3.5 & .5 \\
\hline $\begin{array}{l}\text { Musical Futures works with classes of all } \\
\text { sizes }\end{array}$ & $16 \%(4)$ & $48 \%$ (12) & $28 \%(7)$ & $8 \%(2)$ & 2.7 & .8 \\
\hline $\begin{array}{l}\text { Musical Futures works equally well with } \\
\text { all students }\end{array}$ & $4 \%(1)$ & $52 \%(13)$ & $32 \%(8)$ & $12 \%(3)$ & 2.5 & .8 \\
\hline
\end{tabular}

Figures in brackets indicate the number of respondents

Changes to pedagogy: In the interviews teachers reported that there had been considerable change to pedagogy including greater emphasis on student learning and group work, the introduction of instrumental skills earlier, changes to assessment within class and changes to the nature of the national assessments adopted.

There was complete agreement (100\%) that Musical Futures had introduced new ideas into the classroom. One teacher who was experienced in using Musical Futures commented on the way that teaching had changed:

'My whole outlook on the way kids should be taught has changed since I started. I used to stand over the kids, watch them like a hawk, and these days I'm like a facilitator so I'll give them a task, they'll have their objectives and they always follow the same three part lesson as you'd find in any 
lesson. By shifting the onus from the teacher to the pupil, it completely changes your outlook on lessons and on the kids. ' (Head of Music)

By the time of the interviews in phases 2 and 3 there were indications that the teachers had progressed to perceiving Musical Futures as a more general approach which underpinned much of the curriculum:

'Musical Futures is that idea of the knowledge of something rather than about something.' (Head of Music)

Another teacher described it as 'not even playing by ear, it's working by ear.'

The changes in conception led to the introduction of different activities in different genres, for instance, song writing, film music and working with other subject areas. The teachers reported that there had been few major changes to the curriculum over the period of time of the research but that they reviewed their practice every year:

'I don't think there [have been] any significant changes. We constantly review our curriculum so it will definitely shift and we'll try different things out.' (Music Teacher)

However, not all teachers were enthusiastic about the changes that had been brought about. One relatively inexperienced teacher expressed reservations about Musical Futures:

'I've only been teaching for two years and all I've ever done with Year 9s is Musical Futures so it's difficult to say whether it's working or not. Even with our Year 8 s we still put in those informal teaching strategies... I think that informal teaching is a good thing for the students because it gives them a bit more confidence than learning, rather than being very rigid with exactly what you have 
to do and it has to be correct. But I think it's important that we do need to have classes sat down, actually doing written work and listening work...I think that needs to be changed somewhat and have a bit more of a tradition of actually being able to sit down in a classroom, in a classroom setting and being able to do that as well.' (Head of Music)

Focus on learning and group work: One of the key themes emerging was the way in which Musical Futures encouraged staff to concentrate on how students learn rather than on how the teacher 'delivers the curriculum':

'It's contributed to making us focus on learning in the department. What is musical learning? How do they learn? How do they learn best? We've redone all our schemes of work in response to that.' (Head of Music)

Group work was viewed as key to the implementation of the Musical Futures informal learning model. In focusing on learning teachers made a range of observations about group work. They acknowledged the importance of group work for the students' overall development:

'When they're discussing things as a group they seem to have a bit more of a grasp of what the roles are and who's leading this. The way they sort of discuss ideas, I think it does build them up especially for group work.' (Head of Music)

The teachers also recognised that the group work provided opportunities for developing team working and the consequences if this did not occur:

'A lot of the work is working in a group often without an adult supervisor so the group skills, learning to deal with each other, learning to listen to each other, learning to respect each other are huge. Of course that's the difficult thing often in the first term. They can't do that. They just don't 
listen to each other, they just sit and play. And they start realising after four weeks, six weeks, maybe a term, that it's not getting them anywhere. When they listen to each other perform, the band that has been just in their own little world playing while someone's talking, not listening to each other, sound rubbish. They learn from that.' (Head of Music)

Some teachers explained to the students how important working collaboratively was to the success of the project at the outset:

'You say right at the beginning that if you sit there and argue about it for six weeks you're going to have nothing.' (Music Teacher)

'If they don't behave cooperatively then they don't succeed. I've got a group coming up next lesson where there is still a hard core, a small group that I just haven't been able to get through to. You're not going to get perfect behaviour from everybody, most of them cooperate, learn to share and make do, be patient, maybe not have everything they want.' (Music Teacher)

The teachers commented on the way that the students helped each other in the groups:

'The kids learn from each other. One will come out of one group and goes and says, can you help me with the drums, and then that kid comes out of their group and helps them with the drums and then goes back into their group.' (Head of Music)

The teachers generally allowed the students to resolve problems without intervening recognising that they needed opportunities to learn how to co-operate:

'By and large we let them sort it out by themselves.' (Head of Music) 
Where individual students were unable to adapt to the group work situation they were usually given alternative creative work often utilising computer software.

Induction to the musical futures approach for students: The extent of independent learning led some teachers to introduce some of the principles and skills that would be needed earlier:

'The thing about Year 9 work is that's in groups and they're their own bosses. Most of the stuff in years 7 and 8, I'm still leading it. They have a choice of what song we do but in Year 9 it's much more independent. The idea is that we give them the skills so they can be more independent. It makes lessons more interesting. Lots of Year 7 and 8 classes are making more progress. It's only the second year of doing it as a full curriculum.' (Head of Music)

Interviews with the music teachers undertaken in Phases 2 and 3 asked questions about transition from primary school. All of the teachers raised issues about the lack of skills of the students transferring:

'In my experience, when we get the kids in, in Year 7, their musical knowledge is pretty limited. I've worked as a primary school teacher and I know that music is kind of shoved out. In terms of the curriculum offer it's not a huge priority. A lot of the kids we get here are pretty weak when they come in and obviously we've got the ones who've been learning an instrument privately and are pretty good.' (Music Teacher)

\section{Issues relating to assessment}

Assessment in the classroom: Some teachers raised concerns about assessment procedures in Musical Futures work outlining that they had experienced difficulties in relation to the National 
Curriculum levels in music. While some performances were felt to be easy to assess others were more problematic:

'Singing a part, if it's rapping it sort of is singing. But it's hard to actually put it with the national criteria. If there's somebody obviously outstanding like a guitarist who's playing the solo bit on a guitar you can obviously see that's really been top notch but if someone's playing a drum part, and they've actually worked it out but they're not actually doing the whole thing, they're just doing something simple, it's quite hard to assess.' (Head of Music)

Other teachers felt that the Musical Futures approaches simplified assessment:

'I think it makes assessment quite straightforward really because you can be familiar with all the groups because you can spend time with each group, it's common sense really. You can see who's got the greatest input who isn't putting in so much effort, and because we like to record things you've got things as evidence.' (Music Teacher)

'It's far easier to assess kids doing Musical Futures kind of work than traditional work. I use video a lot so from videoing a class band you can see who can, who is nearly and who can't very, very quickly. There's no hiding place.' (Music Teacher)

One school, during Phase 1 of the research, developed their own criteria based around the Musical Futures work to assess the levels:

'People perceive it to be a one-off rock and pop based curriculum, a have a good time project. So initially we wrote our own levels. We gave difficulty levels for instruments and we wrote that into our assessment structure so if we saw somebody playing something very challenging we would give credit for that. If we see somebody doing peer leadership for example, you may not play anything 
but have actually brought that group together, then we would give credit for that too.' (Music Teacher)

The later Phases of the research showed a greater emphasis on the importance of self and peer assessment:

'We do a huge amount of self-assessment and peer-assessment. In performance, they'll play. The kids will say what they thought was successful about their performance and an area for improvement and they get so used to that. The kids get used to talking about their work in a supportive way.' (Music Teacher)

Teachers' interviews in Phases 2 and 3 seemed to be aware of the need to demonstrate progress using the various assessment measures adopted by schools and to have incorporated this into their teaching on a routine basis:

'We use National Curriculum standards. We give them an $a$, $b$ or c. It's to give the kids something to aim for.' (Head of Music)

National examinations: Over the period of the research there was an increase in the number of schools adopting the Business and Technology Education Council (BTEC) examinations instead of students taking the General Certificate of School Education (GCSE):

'We have introduced the start of the BTEC certificate in Year10. That seems much better, much more appropriate for the kids than the GCSE which is more traditional. Nobody's dropped out of BTEC. Some drop out of GCSE, it's too much like hard work.' (Head of Music) 
However, despite early enthusiasm, the later interviews showed that offering BTEC in Key Stage 4 created problems in some schools:

'When we offer the BTEC, because of the qualification, it's a double option. They have to choose a subject from each column and if you're doing a BTEC it takes up two columns. So there were people who were put off.' (Head of Music)

In some schools the later interviews revealed that changes had been made to the overall curriculum to adapt to the increasing number of students taking GCSE, some of whom were going on to take A level music:

'Next year there's been a feeling from other members of the department that we need to maybestep back a little I suppose from what they would call a Musical Futures approach. A little bit more history and a little bit more theory I think is how it would be described. I think it's partly due to the big uptake at GCSE which has then gone on to Key stage 5 as well, and people feeling that they weren't prepared from Key Stage 3 to go into Key stage 4.' (Head of Music)

The different skills of those taking music at Key Stage 4 impacted on the teaching of GCSE:

'It's people coming in doing GCSE music who are non-traditional musicians and whereas in the past we've always had some do that, it's now coming to the point where maybe half the class is like that. It's taken away the elitism which is not a bad thing but it certainly does change the dynamic because you've got those grade 6 and upwards kids in the class next to people who used to like doing Musical Futures and so have chosen music. There's certainly a groan when it comes to doing what they call a GCSE theory lesson. There's much more desire to do practical work all the time.' (Music Teacher) 
In some schools staff wanted to maintain the GCSE option and run a BTEC option alongside it:

'I don't want to lose GCSE because we have some very traditional learners at school. I've got grade 8 pianists, grade 7 violinists and I can't lose that to having a BTEC, because they aren't BTEC students, they're traditional GCSE students.' (Head of Music)

Overall, there were tensions in relation to progression to and through Key Stage 4. While BTEC seemed to be a more appropriate succession route following Musical Futures it limited opportunities for those students who played classical instruments and needed GCSE for university entrance or the opportunity to take A levels. Music Teachers felt that it was unlikely that they would be able to offer both options in the long term so they were faced with difficult choices.

\section{Resources}

Teachers were asked to indicate if there were sufficient practice rooms to be able to implement Musical Futures successfully. 57\% indicated that they had sufficient, the remainder did not (see Table 6).

Table 6: Teaching using Musical Futures (Phase 1)

\begin{tabular}{|l|l|l|l|l|l|l|}
\hline & $\begin{array}{l}\text { Strongly } \\
\text { agree }\end{array}$ & Agree & Disagree & $\begin{array}{l}\text { Strongly } \\
\text { disagree }\end{array}$ & Mean & SD \\
\hline $\begin{array}{l}\text { There are enough practice rooms or } \\
\text { other spaces for Musical Futures }\end{array}$ & $11 \%(3)$ & $46 \%(12)$ & $35 \%(9)$ & $8 \%(2)$ & 2.6 & .8 \\
\hline $\begin{array}{l}\text { I have enough resources for Musical } \\
\text { Futures }\end{array}$ & $23 \%(6)$ & $35 \%(9)$ & $35 \%(9)$ & $8 \%(2)$ & 2.7 & .9 \\
\hline $\begin{array}{l}\text { There is enough lesson time for } \\
\text { Musical Futures to work well }\end{array}$ & $16 \%(4)$ & $48 \%(12)$ & $36 \%(9)$ & & 2.8 & .7 \\
\hline
\end{tabular}

Figures in brackets indicate the number of respondents

Typically, accommodation was not appropriate for the nature of the activities: 
'We don't really have enough space. We've got this one big room but the other rooms are quite small and they're quite far away from my classroom.' (Music Teacher)

There were particular issues relating to noise especially during the summer months when schools had examinations. The other issue related to timetabling and the difficulty of running Musical Futures classes simultaneously because of limited numbers of instruments or practice spaces. This meant that teachers had to find alternative, sometimes less appealing, activities for a class, giving priority to one class over another for practical work.

'The organisation of it has certainly been a challenge and the whole issue of timetabling and how to make it effective and work.' (Head of Music)

Teachers were also asked if they had sufficient resources to implement Musical Futures. 58\% indicated that they did, the remainder did not (see Table 6). The particular issues which concerned teachers related to dealing with electric equipment:

'You can be running around looking for jack leads and you know trying to get amps to work if you haven't got that equipment. You know I would love to be in a situation where we had every single room totally equipped with a kit and an amplifier and they just walk in and they play. Obviously, there are financial constraints there. We do the best we can. That for me is the main problem. That's what drives me mad.' (Music Teacher)

'You've got 26 kids with guitars, and leads and basses and drum sticks and kits and mics and XLRs and jack to jacks that aren't working. It's a logistical nightmare, with one teacher having to deal with five different groups all at the same time.' (Head of Music)

There was also an issue relating to the normal wear and tear on instruments: 
'We've got guitars and basses and things like that. Drum kits do get beaten up and that's not kids treating them badly or vandalising it's because sometimes they get lugged around and stuff like that.' (Head of Music)

The other resource issue raised by teachers related to staffing. The need for a technician was raised by several Heads of Music:

'You have to have a technician. We are now getting one, but when you've got that amount of equipment and if you're lucky enough to have that amount of equipment, you have to have someone who's going to look after it.' (Head of Music)

Other teachers raised the issue of needing staff to support the group work and provide expertise in relation to different instruments:

'The staffing of it has been quite a challenge. Pretty much it's just been about using our peripatetic teachers, getting them involved for some sessions. Our technician does quite a lot although strictly speaking he's not supposed to support music lessons.' (Head of Music)

'The only issue for us is the staffing. That's a common problem I guess for schools doing Musical Futures because really if you're going to do those projects well you need extra hands on deck.' (Music Teacher)

$64 \%$ of teachers agreed that there was sufficient time to implement Musical Futures, while $36 \%$ disagreed (see Table 6). One teacher indicated: 
'Oh, it has its pros and cons definitely. I do like to some degree the freedom that it's given us but it's difficult to manage in terms of resources and space, and when you've only got one hour lessons it's sometimes a bit of a challenge to fit everything in, but overall positive.' (Music Teacher)

Teachers were asked about issues relating to health and safety. Staff set up rules and routines that helped with dealing with the electric equipment:

'Obviously you've got wires all over the floor and amps. I think on the whole most of the students are well-informed and they go along with the rules that are put down. I think as I say when you get down to the bottom set Year 8 that's when you've got to be monitoring all the time. Definitely that is a consideration.' (Music Teacher)

The other issue raised related to the possibility of damage to hearing:

'We used to have proper drum kits and kids would smack them and they are incredibly loud but we have electric drum kits now which you can turn down, amps that you can turn down, you can set them to safe levels. I think schools need to start thinking about music teachers' hearing generally.' (Music Teacher)

\section{Perceived challenges to the introduction of Musical Futures in schools}

The greatest perceived barrier to adopting Musical Futures was reluctance on the part of teachers and fear of losing control:

'I think any teacher can do it, but a lot of teachers won't. And by that I mean they find the lack of control difficult. They find teaching something they're not secure with difficult.' (Head of Music) 
Teachers were reported to need to learn to trust their students:

'The biggest thing with my staff... they're scared kids are going to abuse the trust. Once you trust the kids a bit it becomes a lot easier to get on with.' (Head of Music)

'Relationships with your kids, massive, trusting them, and them trusting you, because you're trying things out, you're both trying different things out, you're putting them in situations they haven't been in and you're putting yourself in situations you haven't been in, you've got to have that relationship with them.' (Music Teacher)

For some teachers there were perceived to be issues relating to specific musical skills:

'I think a lot of teachers don't actually have the skills, the musical skills. There are people I've come across who wouldn't know one end of a guitar from another. You need to be able to play a few chords, know where a few notes are to show kids. Same with drums, keyboard. I know it's all personalised learning but still, they do need a bit of guidance.' (Head of Music)

There was a perception that some teachers would feel ill-prepared because of the way that they had been trained and the way that they had taught previously:

'I think if you've got a staff that has taught in a different way for a long period of time, it is really very difficult. It is like taking all the things - the scaffolding that they hang on to - away, and just saying now go and do it, and I think this needs to be addressed.' (Head of Music)

Most of the teachers had attended a training day prior to the introduction of Musical Futures. Learning through observing others adopting Musical Futures approaches was perceived to be successful, although several felt that training in managing small group work would have been 
useful. Some of the staff were working with Initial Teacher Education programmes to introduce Musical Futures. Those who did not class themselves as 'popular' musicians indicated that they needed to learn new instrumental skills, albeit at a fairly basic level.

\section{Discussion}

There are of course limitations to this research. It was based on Musical Futurres Champion Schools where teachers and the senior management were committed to the approach and were engaged in providing continuing professional development opportunities for other teachers. Similar research undertaken more widely across the sector may have generated different findings. Also, the focus on a small number of schools limited the size of the sample which inevitably constrains the extent to which the findings can be generalised.

Overwhelmingly, the teachers were positive about the impact of Musical Futures on their teaching and confidence in teaching. They indicated that their teaching had changed as a result of adopting the Musical Futures approach and that this was for the better. Musical Futures increased reported teacher effectiveness, confidence, and enjoyment. Confidence in teaching instruments had increased but this was less so for singing and teaching other musical genres. Teachers were more aware of the music that students engaged in outside school and most had adapted Musical Futures to fit with their personal approach to teaching and learning and the needs of their students. Lessons were more practical, more student-led and there was a focus on group work. Musical Futures encouraged staff to concentrate on how students learned rather than on how the teacher 'delivered the curriculum'. These findings reflect those found in the Australian context (Jeanneret, McLennan \& StevensBallenger, 2011). At first sight this suggests a way forward for classroom music education. However, based on the evidence from Sweden, where informal learning has been the norm for many years, it appears that adopting informal learning of popular music in the classroom does not ensure the enhanced motivation and commitment of all students and presents particular problems in relation to progression and the development of musical knowledge and skills (Georgii-Hemming 
and Westvall, 2012). While the approach clearly has some value, it may have most benefit for students and teachers if it is implemented as part of a more balanced music curriculum. The findings reported here on the implementation of Musical Futures suggest that this is the approach which is being adopted by teachers even in Musical Futures Champion schools.

There were challenges, even in the Champion Schools where senior staff in the school were very supportive of the initiative. Issues were raised relating to accommodation and its appropriateness for Musical Activities, time to enable students to work productively, access to and maintenance of instruments, technical support and staffing to provide the levels of support needed by the students. The location of the music department could also be an issue in relation to noise particularly during examination periods. Where facilities were appropriate and students were working in practice rooms there was less potential for the widespread perception of off task or disruptive behaviour.

Teachers were divided as to whether implementing Musical Futures was stressful. The nature of the teaching required total commitment. This was exhausting but also exhilarating. A key barrier to the implementation of Musical Futures was teachers' fear of losing control of classes. The lack of control was anxiety provoking for some teachers but this tended to reduce after teachers had implemented Musical Futures over time and realised that the quality of the work produced by the students was high. Staff gained considerable personal satisfaction from teaching adopting the Musical Futures principles because of the motivation, enthusiasm, and success of their students.

Initial concerns about assessment of Musical Futures outcomes in relation to the National Curriculum levels were overcome with some schools developing detailed protocols for use with teachers and students. There were perceived advantages of the group work in being able to assess the work of individuals more easily, and of implementing formative and peer assessment procedures. 
Teachers commented favourably on the increase in the number of students continuing with music after Key Stage 3. This was attributed to the opportunities students had to develop instrumental skills, and their enjoyment in working independently. Some schools had moved from the GCSE curriculum to BTEC seeing it as a more logical progression from the Musical Futures work. However, there were tensions in some schools between meeting the needs of those who had well developed 'classical' music skills and needed to take GCSE music in order to progress to A level music and those whose experiences were limited to Musical Futures for whom BTEC was deemed to be more appropriate. In some cases courses were over-subscribed and selection procedures had been introduced. With pressure on school budgets there was concern that schools would not be able to continue to offer both GCSE and BTEC.

Teachers were increasingly recognising the need to develop instrumental skills earlier. This has implications for teaching in the primary school and the early years of secondary school. Students needed access to instruments for practising. Many needed support in developing interesting practising strategies that would help to alleviate the negative associations that had developed with previous instrumental learning experiences. Ways to ensure that students can develop technically on instruments, should they wish to do so need to be considered. Peripatetic instrumental teachers might hold workshops to support this.

While, the majority of teachers held positive perceptions of the impact of adopting the Musical Futures approach on their teaching and skill development, these teachers were all working in Champion schools where they had the full support of the senior management in the school. In schools with less supportive management, teachers may find the barriers, as outlined by Gower (2012) as too great. In addition, the participants tended to be knowledgeable about and have skills relevant to the teaching of popular music. This is not the case for some teachers many of whom are likely to have been trained in the Western classical tradition and may have limited skills relating to popular music. Participants reinforced this stressing the need for training to be available in engaging 
with Musical Futures, managing small groups and developing some basic skills on the instruments used in 'popular' music. While Musical Futures offers such opportunities and the approach is increasingly being included in Initial Teacher Education programmes (see for instance, Finney \& Philpott, 2010) music teachers may feel that in the current educational climate in England the challenges are too great for implementation to be feasible.

\section{Conclusion}

Adopting an informal approach to teaching music supported teachers in developing a range of new skills which increased their confidence in teaching and their enjoyment of it. Their main rationale for adopting this approach was to make teaching more relevant to the needs of their students thus enhancing their motivation. Despite this, the Swedish experience suggests that in the longer term the impact on students is not sustained as teachers are unable to cater for the musical preferences of all students. There were also issues relating to resources and the exhausting nature of the work for the teacher. Overall, facilitating informal learning based on popular music might usefully constitute one element of a teacher's pedagogical toolkit but based on the evidence where such approaches have been in place for many years it may be more appropriate for it not to become the only approach adopted.

\section{References}

Benson, F. (2012) Thrown in at the deep end: Informal lerning in a primary music classroom. Unpublished undergraduate thesis, Sydney Conservatorium of Music, University of Sydney.

Bergman, A. (2009) Vaxa upp med music: ungdomars musikanvandande i skolan och pa fritiden (Growing up with music. Young people's use of music in school and during lesson time. Phd Dissertation, University of Gothenburg. 
Braun, V. and Clarke, V. (2006).Using thematic analysis in psychology.Qualitative Research in Psychology, 3, 77-101

Button, S. (2006) 'Key Stage 3 pupils' perception of music'. Music Education Research, 8(3), 417431.

Cohen, L., Manion, L., Morrison, K. (2003) Research methods in education. London:

RoutledgeFalmer.

dAmore, A. (2014) Ten Years of Musical Futures: Take, Use, Innovate, Share. London: Paul Hamlyn Foundation

Evans, S.E., Beauchamp, G., \& John, V. (2015) Learners' experience and perceptions of informal learning in Key Stage 3 music: a collective case study, exploring the implementation of Musical Futures in three secondary schools in Wales, Music Education Research, 17(1), 1-16.

Finney, J \& Philpott, C. (2010) Informal learning and meta-pedagogy in initial teacher education in England, British Journal of Music Education, 27(1), 7-19.

Georgii-Hemming, E (2006) Personal experiences and professional strategues. Music Education Research, 8(2), 217-36)

Georgii-Hemming, E. \& Westvall, M. (2010) Teaching music in our time. A study of student teachers' reflections on participation, inclusion and the right to musical development in their school-based music teacher education, Music Education Research, 12(4), 353-67. 
Georgii-Hemming, E. \& Westvall, M. (2012) Music Education: A personal matter? Examining the current discourses of music education in Sweden. In S. Karslen \& L Vakeva (eds) Future prospects for music education: Corroborating informal learning pedagogy. Newcastle on Tyne, UK: Cambridge Scholars Publishing (pp97- 114).

Gower, A. (2012) Integrating informal learning approaches into the formal learning environment of mainstream secondary schools in England. British Journal of Music Education, 29(1), 13-18.

Hallam, S., Creech, A and McQueen, H. (2009) Musical Futures: A case study investigation, an interim report from the Institute of Education, University of London for the Paul Hamlyn Foundation. London: Institute of Education.

Hallam, S., Creech, A and McQueen, H. (in revision) Teachers' perceptions of the impact on students of the Musical Futures approach, Music Education Research

Jeanneret, N. (2010) Musical Futures in Victoria, Australian Journal of Music Education, No. 2, 148-164.

Jeanneret, N., McLennan, R., \& Stevens-Ballenger, J. (2011) Musical Futures: An Australian Perspective Findings from a Victorian Pilot study. Melbourne Graduate School of Education, Melbourne University.

John, V \& Evans, S. (2013) Musical Futures: Summary of the Findings of the Wales Pilot 20112012. Doi. hpps://www.musicalfutures.org/resource/27964/title/musicalfutureswalespilot201112. Accessed 14-01-15 
Karslen, S. \& Vakeva, L (eds) Future prospects for music education: Corroborating informal learning pedagogy. Newcastle on Tyne, UK: Cambridge Scholars Publishing.

Lamont, A., Hargreaves, D.J., Marshall, N.A., and Tarrant, M. (2003) 'Young people's music in and out of school', British Journal of Music Education, 20(3), 229-241.

Little, F. (2009) 'An Exploration into the Uptake Rates of GCSE Music with a Focus on the Purposes of Music in School'. Unpublished EdD thesis, University of Durham.

McQueen, H. \& Hallam, S. (2010) Music in the secondary school. In S. Hallam \& A. Creech (eds) Music Education in the $21^{\text {st }}$ Century in the United Kingdom: Achievements, analysis and aspirations. London: Institute of Education, University of London.

Ofsted (2003) Music in Secondary Schools: Ofsted subject reports series 2001/02 (HMI 811). London: Ofsted.

Ofsted (2009) Making More of Music: An Evaluation of Music in Schools 2005/08. London: Ofsted.

Ofsted (2011) Music in schools: wider still and wider. Quality and inequality in music education 2008-2011. London: Ofsted.

O’Neill, S \& Bespflug, K. (2011) Musical Futures Comes to Canada: Engaging Students in RealWorld Music Learning, Canadian Music Educator/ Musicien Educateur au Canada, 53(2), 25.

Skolverket (Swedish National Agency for Education) (2004) Nationell utvardering av grundskolan 2003. Bild, him-och konsumentkunskap, idrott och halsa, music och slojd (National Evaluation of the Compulsory School in 2003. Subject Report. http://www.skolverket.se/publikationer?id=1385 
Wright, R. (2002) 'Music for all? Pupils perceptions of the GCSE music examination in one South Wales secondary school', British Journal of Music Education, 19(3), 227-241.

Younker, B.A., Wright, R., Linton, L., \& Beynon, C. (2012). "Tuning into the Future: Sharing Initial Insights about the 2012 Musical Futures Pilot Project in Ontario" Canadian Music Educator 53.4 (2012): 14-18. 